\title{
UNIVERSITY STUDENTS DURING HISTORICAL DEVELOPMENTS OF THE UNIVERSITY, 650 YEARS OF THE JOURNEY TO KNOWLEDGE AND UNDERSTANDING
}

\author{
Alexander Schirger \\ Consultant in Medicine Mayo Clinic, Department of Medicine, Division of Cardiovascular Diseases, Division of
} Hypertension, and Professor of Medicine Mayo Medical School, Rochester, Minnesota

Mister Chairman, it was with a great deal of joy and a simultaneous sense of profound humility that I had accepted the invitation of Professor Daum and the organizing committee of the symposium on the University and Its Students, within the framework of the commemoration of the 650th anniversary of the founding of Charles University, to participate in today's program. Knowing there are probably many who would be able to offer these reflections with greater precision and perhaps a more sharpened focus particularly directed at the years when I was absent from the country, imparted a sense of hesitation. Nevertheless, I undertook the codification of my memories with a great deal of enthusiasm hoping to transmit to today's students not only reflections from the past but deductions for the future.

Having been born in Prague and having spent my early childhood in Prague, I had the privilege of becoming, very early in life, familiar with classical works of the Czech literature, like the book by Zikmund Winter on Mr. Kampanus or some of the works dealing with the period after the defeat of the Czech National Forces in 1620 on the White Mountain and it's repercussions on the university. Little did I suspect, as a young boy reading what appeared to be essentially historical novels, that some of the same realities, in much harsher form, I will have the opportunity to witness reenacted in my own lifetime. Following the death of my parents, I returned to Prague as a citizen of the United States of America and continued my primary and secondary education there. Our otherwise peaceful life was interrupted by the events of September of 1938 when the nation was united and mobilized with maximum effort in a unified will to withstand, at whatever cost, the forces of aggression. The opportunity to exercise that will was denied to the nation by the leadership for reasons that I am sure will be debated for years to come. In those days in September of 1938, the students of Charles University were equal to others expressing readiness to defend freedom.

Czechoslovakia was abolished in 1939, by the voluntary sessenion of Slovakia into an independent state and by the occupation of the remnant of the historic lands, that is Bohemia and Moravia, by the German army.

On October 28, 1939, during a peaceful demonstration, one of the Czech university students, Jan Opletal, was shot and wounded. He died several days later, and on November 17, 1939, thousands of university students reverently and peacefully attended his funeral. This was deemed to be a provocation by the German authorities who then, that night, closed all schools of higher learning including Charles University for a six-year period. About a thousand students, who were engaged in the pursuit of acquisition of knowledge and betterment of themselves, were taken to concentration camps. Graphic testimony to this was when, on the morning of November 18, I awoke and found the building in which we lived occupied by SS troupers patrolling the entry and clearly occupying all the university premises. Thereafter, followed the five long years of war, until the hope for liberation by the western allies in 1945, which for the city of Prague and Charles University never took place since it had been decreed that such will need to be carried out by the Soviet Armed Forces. Immediately after liberation in 1945, there was a great deal of enthusiasm, that I had witnessed personally, by the students who had been denied an opportunity for five years to return to their Alma Mater. Provisional spaces had to be utilized and yet not all could be accommodated. It was then, as an American Citizen, I had enrolled into the School of Medicine of Charles University. At that time, without printed text books and, in fact, ironically largely in anatomy relying on German texts, we crowded into the large hall of Lucerna and anxiously listened to our professors' attempts to teach us the foundations of the basic sciences and medicine in a way that, at least for me personally, served me well throughout my professional career. It illustrated the fact that, while physical premises are important, it is the will to learn and the will to teach that is most important. The first lesson, perhaps, to learn and to carry away from those heady days of liberation in 1945. The International Congress of World Students, which convened in Prague in 1945, was unfortunately strongly hijacked by leftist forces and, thus, tainted in some respects the memories of those it was intended to honor and remember, the ones fallen either in the takeover of the university in 1939 or subsequently deceased in concentration camps.

Thereafter, ensued two and a half years of peaceful learning, and the course of the university returned to its usual business, which is education, acquisition of knowledge, 
and the forming of academic bonds that were to last for life. We witnessed in the summer of 1947, as Czechoslovakia had the opportunity to join the Marshall plan that winds of change were again blowing and perhaps not auguring well for the university and its students. The communists tried to control some of the student organizations. In February of 1948, the then leadership of the Czechoslovak state failed for the second time by yielding to the forces of evil, this time coming from the left. It was the students of the university who were the sole voice of protest. I never forget the fact that when the unconstitutional Coup d' etat occurred, it was not the populus that was out in the streets, but it was the 40,000 students of Charles University who peacefully marched from all corners of Prague despite the fact that the communist police attempted to block their entry to the castle to present their petition to president Beneš. It always will be counted as one of the more disgracing acts of his presidency that he refused to see them in that critical moment of the nation.

Eventually, just like the troops in Jerusalem needed to workup their courage 2,000 years ago to arrest their victim, so here, it took the communist police several attempts to overcome their fright and the awe at observing students singing the national anthem, before finally, with rifle butts, they charged the crowd and dispersed them, arresting many. I had an eye witness account of this from my wife, who was running down the streets of Mala Strana in an attempt to escape both injury and arrest. I, myself, took refuge, as an American citizen, in the United States Embassy and witnessed what appeared to be the only and last protest of pro-democracy forces. While in 1939 the nation was facing five years of subjugation, in 1948 the prospects were much darker and longer. It, in fact, took 20 years before the first signs of spring arrived which, again, were crushed by the invasion of five eastern block nation's armies on August 22, 1968. While the resistance of the nation was more coordinated, it was the tragic fate of Jan Palach who expressed, in his act of self-immolation, the understandable, yet not commendable, feeling of frustration that the nation felt having its hopes of a new spring crushed again.

In the years between 1968 and 1989, it was, again, the university students who were vocal challengers to the establishment. On November 17, 1989, exactly 50 years after the Nazi onslaught against the students of Charles University and the closing of the university, the Czech student forces, again, assembled for a peaceful demonstration to commemorate the death of Jan Opletal and with the permission of the authorities, marched from the cemetery at Vyšehrad to Wenceslaus Square. At a critical point in route, this peaceful march was stopped by the security forces' onslaught against the students of Charles University. Fortunately, this time, in contrast to 1939 and 1968, the students' stand did not remain without support. The nation did not loose the symbolism of the forces of the current regime mimicking the forces of the Nazi aggressors 50 years ago in suppressing the university. On the next day, the play rights of the nation and the actors' union joined in a shut- down of all public theaters, which turned into a forum of dialogue about the injustices of the regime. When the authorities tried to assemble the people's militia to subdue the students, the militia themselves realized that they would be shooting at their own children. It was at that critical point that the factory workers of the major iron works of Prague, CKD, joined the students' demonstrations, and thus, for practical purposes, sealed off the fate of the regime and gave rise to what has been come to be known throughout the world as the Velvet Revolution.

Czech students certainly cannot claim the heroism and the martyrdom of their co-sojourners in China who were crushed at Tiananmen Square. It is always going to be a testimony to Charles University and an example to the students of future generations that, when challenged with an unjust authoritarian regime, which was bent at suppressing basic human liberties, it was the students, in 1939, in 1948, and ultimately in 1989, who offered the voice that was at one time weak, at one time ineffective, and at one time a catalytic challenge to the nation that led to ushering in of the current era of freedom and prosperity. During this short span of history, there could be witnessed discrimination against students based on racial, ethnic, political, class origin, and religious belief. Whether this was carried out through the brut force or by means of the inquisitional-types of screening committees to whose ire our own chairman, Professor Daum, fell victim, mattered little. The end result was the same. Denial of access to higher education for reasons based on prejudice due to race, ethnicity, social origin, religious belief, or class origin. The price students of this land paid, as a result, is immeasurable. Yet not all was well on the other side of the curtain. When I attended the school of medicine here in Prague, about 50 percent of my classmates were women. When I returned to the United States, there were only two women in the class of 125 at Creighton University. Fortunately, this situation has been remedied with numbers in my home medical school approaching Parity. While we, in Prague, were in part, through circumstances largely color blind, I witnessed in the early 60's in Mobile, Alabama, that I United States Air Force captain, being African American, was asked to sit at the end of the bus. It took the civil rights movement and the ensuing legislation to remedy such and other injustices. Remedial measures were subsequently invoked to overcorrect consequences of past injustices by affirmative action, the value, wisdom, and justice of which have subsequently been both championed and questioned in animated debate and advanced and challenged in the courts. It is well to recall, here, that much of such challenge, in their most vocal form, would come from African American citizens such as the unsuccessful presidential candidate Allan Keith, who could identify with the Black African American political orator, Frederick Douglas, who stated, „Our oppressors have divested us of many valuable blessings and facilities for improvement in education, but thank heavens they have not yet been able to take from us the privilege of being honest, industrious, sober, and intelligent.“ 
A rich country-like America should seek to help its most disadvantaged members not because of what their ancestors endured but because they deserve a chance to reach their full potential here and now as human beings. As Leon Vilseter points out in The Memory of Oppression, oppression perpetuates itself. The real tragedy is that injustice retains the power to destroy long after it has ceased to be real. It is a posthumous victory of the oppressor when pain becomes a tradition. There is an unfair and difficult dilemma of the newly emancipated and enfranchised. An honorable life is not possible if they remember too little, and a normal life is not possible if they remember too much. As we contemplate the lawful, understandable, and sometimes misunderstood attempts to correct the barriers of racial inequality and later racial disharmony among university students, it is well for us to remember that solutions to problems of today might sometimes well be sought in the insights and ancient wisdom of those who preceded us. It is perhaps not inappropriate that as one reflects on the dyssynchronized influence of emphasis on race in our days, to recall, that in this hollow ground, some 650 years ago, a great European, Charles IV, proud of his Czech heritage but conscious of his continental responsibility, formulated ideas and put forth principles upon which it might be well for us to reflect today. As we scan the initial founding document of this illustrious university, it is well for us to admire the vision that he, in this brief document, put forth to the men of his time, his solicitude for citizens entrusted to his care. He felt it imperative that those of Czech native of these lands, not seek, as he put it, the fruits of sciences and wisdom by asking for alms in foreign lands but that they find in their own home a table fully prepared for generous hospitality. In addition, in his fond vision of this university, he also expressed the hope that others would join sons and daughters of this land to seek wisdom, advance in knowledge, and prepare themselves for the task of life not uncognizant of the environment which the beauty of the city, which he perceived even 650 years ago, offered as a milieux for good studies. He pledged his royal imperial favor to all and everyone who would wish to come to visit this university, to be lavishly endowed with privileges and freedoms similar to those enjoyed by the professors, teachers, and students of the universities of Paris and Bologna.

Translated in today's language, the farseeing founder of this illustrious university had pledged equal opportunity for all, native and foreign, based on the recognition of their dignity and on the obligation that this land and those entrusted with the grave responsibility to govern it even in the year of 1348 should provide equal opportunities to all based on their human dignity and the potential they harbor as human beings. Lessons well for us to contemplate and more importantly to put in practice throughout academia the world over. That, my dear friends, I believe would be the legacy of Charles IV, the farseeing founder of this illustrious university were he today address the topic I was asked to discuss. In recognizing the principles that he enshrined in the founding bull and applying them to the academic life to- day, we shall pay the greatest and deserved homage to the man who, by several centuries, outdistanced through his vision the course of history.

It is true that knowledge is best advanced in peaceful times. It had been said by Horace that „inter arma silent musae." Thus, we look to the times of challenge and stress where our predecessors excelled often in heroism and while we view their acts with admiration, we also are cognizant of our own obligation to make the best use of the current day and make optimal use of the opportunities given to us. While doing that, we should never lose sight of the lessons of the past and be vigilant to the emergence of those forces that would challenge life, freedom, and human dignity. By doing so, we will remain students, professors, alumnae and alumni of Charles University, true to its mission given to us upon entry and reaffirmed upon graduation. May this university, carrying forth the ideas and vision entrusted to it by its founder, prosper in years to come and continue to serve as a beacon not only to this blessed land but also to lands and people beyond the shores of this continent. For this, I would like to conclude by offering my humble wishes that this comes true. Universitas Carolina Vivat, Crescat, Floreat.

Thank you very much.

Alexander Schirger, M.D., Professor of Medicine Mayo Clinic Medical School and Consultant in Medicine, Department of Medicine, Division of Cardivascular Diseases was born in Prague, October 3, 1925. After the death of his parents he returned from the USA to Prague as a citizen of the United States of America and continued his primary, secondary and medical studies here. He graduated from the Faculty of Medicine, Charles University. In 1951 he returned to the USA. He is an internationally known internist, angiologist and researcher especially concerning the pathophysiology and therapy of hyper- and hypotension. He is the member of many scientific societies and was the president of the XIII ${ }^{\text {th }}$ International Congress of Angiology in the USA. He has been cooperating closely with the Faculties of Medicine and Institutions in Czech Republic, such as the Foundation of Olga Havlová. He was a member of the Scientific Board of the Faculty of Medicine in Hradec Králové. He delivered several lectures at our faculty and was awarded the gold medal of the Faculty of Medicine. He was also invited to deliver the ceremonial speach on the occasion of the 50th anniversary of its foundation. As well, he was invited to participate in the Conference „The University and Its Students“ and the Rector of the Charles University awarded him the Jubilee Commemorative Medal coined on the occasion of the 650th Anniversary of Charles University in 1998. Thanks to his efforts, many medical students and doctors from the Czech and Slovak Republics have enjoyed the stay at Mayo Clinic, including some of our doctors and students.

L. Chrobák 